\title{
SENZIBILIZIRANJE UČENIKA SREDNJE ŠKOLE ZA SPECIFIČNE POTREBE GLUHIH I NAGLUHIH VRŠNJAKA
}

\author{
ZLATKA KOZJAK MIKIĆ ${ }^{1}$, MIRNA ŠABAN ${ }^{1}$, VESNA IVASOVIĆ ${ }^{2}$ \\ ${ }^{1}$ Zdravstveno učilište, Zagreb, ${ }^{2}$ Agencija za odgoj i obrazovanje, MZOS, Zagreb, kontakt: zkozjakm@net.hr
}

Primljeno: 18.04.2017.

Izvorni znanstveni rad

Prihvaćeno: 26.09.2017.

UDK: $376.1-056.263$

Sažetak: Iako je prilagodba potrebama svakog učenika s teškoćama obaveza školskih ustanova, inkluzija gluhih i nagluhih učenika (G/NGL) koji se obrazuju u redovnim školama nije potpuna. Manjak iskustva, stereotipi i nedostatna stručna potpora mogu nepovoljno utjecati na njihovu prihvaćenost te njihov ukupni osobni i socijalni razvoj. Svrha istraživanja bila je prikupiti podatke o stavovima srednjoškolaca prema G/NGL vršnjacima te kreirati i evaluirati program senzibiliziranja za njihove specifičnosti. Prevedenim i adaptiranim Inventarom inkluzije gluhih i nagluhih učenika (Hung, 2005) prikupljeni su podatci povezani s kontaktima: podatci o percipiranoj bliskosti s G/NGL vršnjacima, učestalosti prethodnih dobrovoljnih kontakata s njima te o percepciji razrednog ozračja povezanog s njihovom integracijom. U istraživanju je sudjelovalo ukupno 200 učenika u dobi od 15,5-16,5 godina. Posebno kreiranim programom obuhvaćeno je 105 učenika. Od tog broja, 46 sudionika je pohađalo dva razreda u kojima su bili integrirani G/NGL učenici, a 59 sudionika je bilo u dva razreda bez integracije. $S 95$ učenika program nije proveden i oni su u istraživanju bili kontrolna skupina. Podatci su prikupljeni u dvije vremenske točke; prije i nakon provedbe programa i statistički obrađeni t-testovima, analizom varijance i standardnom regresijskom analizom. Rezultati su pokazali da je percipirana bliskost s G/NGL vršnjacima relativno visoka, odnosno, da su stavovi prema njima pozitivni. Najmanje pozitivne stavove imali su učenici u razredima koji imaju G/NGL učenika. Provedeni program nije pridonio promjeni stavova. Za predviđanje stavova pokazao se značajnim doprinos prethodnog češćeg dobrovoljnog kontakta s G/NGL učenicima, pozitivnija percepcija razrednog ozračja u odnosu na njihovu integraciju i prisustvo G/NGL učenika u razredu. Rezultati se komentiraju u kontekstu sličnih istraživanja, učinkovitosti provedenog programa te se donose preporuke koje bi mogle pridonijeti inkluziji G/NGL učenika.

Ključne riječi: stavovi; gluhi i nagluhi učenici; inkluzija

\section{UVOD}

Prevalencija oštećenja sluha u općoj populaciji u svijetu iznosi nešto više od 5\% (WHO; 2012). Podatci prikupljeni u Hrvatskoj (Registar osoba s invaliditetom RH; 2015) pokazuju da u našoj zemlji ukupno 615 mladih ljudi u dobi od 15-19 godina ima invaliditet uzrokovan gluhoćom, od čega je 267 djevojaka i 348 mladića. Većina ih je integrirana je u redovnim odgojno- obrazovnim ustanovama, pa se s obzirom na to, može postaviti pitanje je li njihova integracija u redovne škole dovela i do njihove inkluzije?

Integracija podrazumijeva činjenicu da se gluhi i nagluhi učenici (G/ NGL) mogu školovati izvan posebne odgojno-obrazovne ustanove, što je u RH i zakonski regulirano. Inkluzija je, međutim, nadređeni pojam, cilj kojem se teži. Podrazumijeva uvažavanje različitosti (Imširagić, 2012) i kompletnu, a ne samo akademsku uključenost G/NGL učenika u redovni obrazovni sustav. Za razliku od integracije, koja podrazumijeva fizičku uključenost učenika $\mathrm{s}$ teškoćama u redovne škole, inkluzija se, pored uključenosti, odnosi i na njihovu prihvaćenost. Ukoliko je odnos između čujućih i G/NGL učenika ravnopravan, koristi od inkluzije mogu imati i jedni i drugi, na što ukazuju primjeri inkluzivnih škola u drugim državama, npr. u Švedskoj (Black 2011) i Italiji (Teruggi, 2014).

Integracija G/NGL učenika se u našoj zemlji provodi od sedamdesetih godina prošlog stoljeća (Ivasović, 2014), a zakonski je regulirana po prvi put donošenjem Zakona o odgoju i osnovnom obrazovanju (1980) i kasnijeg Zakona o odgoju i obrazovanju djece u osnovnoj i srednjoj školi (2008). Inkluzija se kao pojam u RH spominje tek u kasnijim dokumentima i temelji se na Konvenciji o pravima osoba s invaliditetom UN (2007) te 
Pravilniku o osnovnoškolskom i srednjoškolskom odgoju i obrazovanju učenika s teškoćama u razvoju (2015). Prilagodba potrebama svakog učenika s teškoćama obaveza je školskih ustanova, no inkluzija još uvijek predstavlja izazov, kako za G/NGL učenike, tako i za njihove čujuće vršnjake i odgojno-obrazovne djelatnike. Jedan od razloga može biti nedostatak iskustava i nepripremljenost zbog relativno malog broja G/NGL učenika u redovnim školama kao i činjenica da gluhoća nije vidljiva okolini, pa je tim teže shvatiti i sve njene posljedice (Ivasović, 2014; Nojman Hižman, 2008). Pored toga, obrazovanje nastavnika za inkluzivnu praksu još uvijek nije dovoljno, a stručna podrška nastavnicima $u$ individualizaciji pristupa učenicima s teškoćama u praksi je nedostatna (Bouillet, 2014).

Glede identiteta G/NGL osoba, danas se zajednica gluhih i stručnjaci zalažu za socijalno-kulturalni model gluhoće, prema kojemu G/NGL osobe predstavljaju jezično- kulturnu manjinu, a ne tek skupinu osoba s invaliditetom. Prema ovome modelu, G/NGL se priznaje pravo na vlastiti, znakovni jezik. Ističe se da osnova njihovih eventualnih emocionalnih, obrazovnih i socijalnih teškoća nije gluhoća sama po sebi nego su to neadekvatne reakcije i stavovi okoline. Stavove okoline mnogi autori identificiraju kao iznimno važne za pravu inkluziju G/NGL učenika u redovnim školama (Hung; 2005; Kiš- Glavaš i Pantić, 2002; Rittenhouse, 1987, prema Farber, 2015). Stav je naučena tendencija da se na manje ili više pozitivan, odnosno negativan način, reagira prema određenim osobama, objektima ili situacijama. Stavovi su vrlo važni, ako ne i ključni, za razumijevanje ponašanja pojedinca i ponašanja okoline prema pojedincu. Negativni i diskriminirajući stavovi okoline jedan su od rizičnih čimbenika za emocionalni razvoj G/NGL osoba (Hindley i Kitson, 2000). Čujući učenici u prosjeku nemaju negativnije stavove prema G/NGL vršnjacima u odnosu na stavove prema vršnjacima koji čuju, ali ih ipak znatno rjeđe biraju za prijatelje (Nunes, 2001).

U dostupnoj literaturi spominje se nekoliko faktora važnih za formiranje stavova prema G/NGL osobama. Jedan od najčešćih koji se spominje jest mogućnost kontakta s njima. Nedostatak kontakta pridonosi stereotipima i predrasudama o osobama koji pripadaju bilo kojoj manjinskoj skupini, pa tako i G/NGL, kako to proizlazi još iz Allportove hipoteze kontakta (1954). Kontakt s G/NGL pojedincem značajno pridonosi pozitivnijim stavovima prema čitavoj skupini G/NGL osoba (Hung, 2005). Neki autori naglašavaju kako je kontakt s G/NGL osobom nesumnjivo važan, ali ne bilo kakav kontakt. Presudna je kvaliteta prethodnog kontakta $\mathrm{s}$ G/NGL pojedincem. Pozitivnije prethodno iskustvo pridonosi pozitivnijem stavu prema G/NGL osobama općenito (De Laat i sur., 2013). Podatci o povezanosti dobi, spola i stavova su mješoviti (De Laat i sur., 2013), a čini se da su u kombinaciji s neposrednim kontaktom s G/NGL manje važni (Leutar i Štambuk, 2006). Prema jednom istraživanju, stavovi čujućih učenika od šestog do dvanaestog razreda američkih srednjih škola prema G/ NGL vršnjacima uglavnom su pozitivni. Djevojke iskazuju pozitivnije stavove u odnosu na dječake, ali je ta razlika, iako značajna, zapravo bila vrlo mala. Najpozitivnije stavove imaju učenici srednjoškolske dobi (Hung, 2015). Samopoštovanje se također pokazalo važnom varijablom povezanom sa stavovima prema G/NGL vršnjacima. Adolescenti s višim samopoštovanjem izražavaju pozitivnije stavove (De Laat i sur., 2013). Za stavove i ukupno ponašanje učenika srednjoškolske dobi veliku važnost imaju njihovi vršnjaci, odnosno percepcija načina ponašanja koja je prihvatljiva skupini kojoj pripadaju i/ili žele pripadati, što je važan element $i$ unutar razrednih odjela. Normativna vjerovanja značajan su faktor u socijalnim interakcijama učenika sa i bez teškoća (Hung, 2005). Stoga je percepcija standarda ponašanja i odnosa koji su prihvaćeni u nekom razredu, odnosno ukupnog razrednog ozračja u odnosu na integraciju, zasigurno važan faktor koji je povezan sa stavovima prema G/NGL vršnjacima.

U Hrvatskoj se integracija i inkluzija učenika s različitim teškoćama znanstveno istražuje dulje od 30 godina. Kao osobito važne subjektivne pretpostavke uspjeha socijalne integracije G/NGL učenika istražuju se stavovi nastavnika, čujućih učenika i njihovih roditelja. Ranijih godina ispitivani stavovi roditelja čujućih učenika (Mustać, 1978; Radovančić, 1994; Uzelac, 1989) pokazali su se uglavnom nepovoljnima. Istraživanja stavova nastavnika (Dulčić i Bakota, 2008; Radovančić, 1985 i 1994; Stančić, 1982; Uzelac, 1989) pokazuju neujednačene rezultate. Povoljnije stavove 
imaju nastavnici u predmetnoj nastavi u odnosu na nastavnike razredne nastave, nastavnici iz škola s periferije ili izvan gradskog područja u odnosu na one iz škola u centru grada (ispitivanja za grad Zagreb i okolicu), nastavnici mlađi od 40 godina u odnosu na one starije od 40 godina. Međutim, i u nekim novijim istraživanjima dobiva se da su stavovi nastavnika prema učenicima s teškoćama općenito još uvijek nepovoljni, to nepovoljniji što je teškoća više izražena (Leutar, 2002). Bosnar i Bradarić-Jončić (2006 i 2008) ispitale su stavove oko 450 prosvjetnih djelatnika (odgajatelja i nastavnika u vrtićima, osnovnim i srednjim školama) o inkluziji G/NGL učenika u redovne vrtiće i škole. Rezultati su ukazali na razlike u stavovima s obzirom na obrazovnu razinu, pa su najpovoljnije stavove iskazali odgajatelji, a najnepovoljnije srednjoškolski nastavnici.

Za razvoj stavova djece prema vršnjacima s različitim teškoćama neke od važnih varijabli su razvojna razina učenika s teškoćom, spol, razina poticanja prijateljstva sa strane roditelja djece bez teškoća, kontakt i prethodna iskustvo druženja s djecom s teškoćama (Kiš-Glavaš i Pantić, 2002). U ispitivanjima stavova učenika prema integraciji učenika s teškoćama prevladavaju pozitivni stavovi, ali uz prisutnost nesigurnosti, pri čemu učenice imaju povoljnije stavove od učenika, nešto su povoljniji stavovi učenika u školama izvan centra grada kad je ispitivanje provedeno u gradu Zagrebu (Oberman Babić, 1987, Kunac, 2015.). Na uzorku od 54 učenika od trećeg do osmog razreda osnovnih škola u kojima je bilo integriranih G/NGL učenika u razdoblju od barem godine dana pokazalo se da su stavovi bili relativno povoljni (Uzelac, 1989). Najvažniji utjecaj na formiranje i transformiranje stavova učenika prema integraciji imala je duljina druženja s G/ NGL vršnjakom koja je omogućila stjecanje bogatijeg svakodnevnog iskustva s tim učenicima, pa su povoljnije stavove imali učenici u predmetnoj nastavi, a manje povoljne oni u razrednoj nastavi. Osobito je zanimljivo da se u tom istraživanju pokazalo da su povoljnije stavove o integraciji G/NGL učenika imali čujući učenici od samih G/NGL učenika.

Sve navedeno ukazuje na važnost proučavanja stavova neposredne obrazovne okoline prema G/NGL učenicima, kao i na potrebu razvijanja i implementacije programa senzibiliziranja za nji- hove specifičnosti. Iako relativno trajni i otporni na promjenu, prema nekim autorima stavovi djece osnovnoškolske dobi prema osobama s invaliditetom mogu se mijenjati u relativno kratkom periodu kroz pružanje pozitivnog, izravnog iskustva s djecom s razvojnim teškoćama, kao i kroz neizravno iskustvo; informiranje putem knjiga, vođenih diskusija ili sličnih aktivnosti (Yuker, 1988). Kakva je situacija sa srednjoškolcima? O tome u dostupnoj literaturi nismo naišli na podatke. Uz poznavanje rezultata inozemnih istraživanja važno je ispitati stavove u aktualnom obrazovnom kontekstu, ali i provoditi programe senzibiliziranja za specifičnosti G/NGL učenika koji se školuju u redovnim razredima. Od osobite ih važnosti provoditi s budućim zdravstvenim djelatnicima; upoznati ih s posebnostima komunikacije s osobama oštećena sluha i proširiti te spoznaje informacijama o kulturološkim obilježjima zajednice G/NGL i osnovama znakovnoga jezika kako bi kvaliteta zdravstvene skrbi G/NGL osoba u budućnosti bila unaprijeđena (Pribanić i Milković, 2016).

\section{CILJEVI ISTRAŽIVANJA}

Problem kojim se istraživanje bavilo bio je kako povećati senzibiliziranost srednjoškolskih učenika za specifičnosti G/NGL vršnjaka, odnosno kako poboljšati njihove stavove i povećati interakciju s G/NGL učenicima te kako se te promjene mogu mjeriti. Definirani su ciljevi istraživanja:

1. Ispitati stavove srednjoškolaca prema $\mathrm{G} / \mathrm{NGL}$ vršnjacima

2. Usporediti stavove iskazane prije i poslije provedbe programa

3. Provjeriti mogućnost predviđanja stavova na osnovi uključenosti u program, prisustva G/ NGL učenika u razredu, učestalosti prethodnih dobrovoljnih kontakta s G/NGL učenicima, percepcije razrednog ozračja u odnosu na integraciju G/NGL učenika

\section{HIPOTEZE}

H1: Stavovi prema G/NGL vršnjacima bit će pozitivni.

H2: U razredima u kojima se obrazuju G/ NGL učenici stavovi će biti pozitivniji u odnosu na razrede koji ih nemaju. 
H3: Stavovi iskazani nakon provedenog programa bit će pozitivniji u odnosu na stavove iskazane prije programa.

H4: Stavove sudionika bit će moguće predvidjeti na osnovi uključenih prediktorskih varijabli. Pozitivnije stavove imat će učenici koji su bili obuhvaćeni programom, koji imaju G/ NGL učenika u razredu, koji su prethodno imali više dobrovoljnih osobnih kontakata s G/NGL učenicima i koji percipiraju da je razredno ozračje u odnosu na integraciju G/ NGL pozitivnije.

\section{METODE RADA}

\section{Sudionici}

U istraživanju je sudjelovalo ukupno 200 učenika drugih razreda srednje škole, u dobi od 15,516,5 godina. Sudionici su pohađali više različitih programa medicinskih usmjerenja. Među sudionicima su bile 163 djevojke (81,5\%) i 37 dječaka $(18,5 \%)$.

Ukupno 105 sudionika iz četiri razreda bilo je obuhvaćeno programom senzibiliziranja za specifičnosti G/NGL učenika. Od ova četiri razreda, u dva je razreda bilo ukupno četiri G/NGL učenika koji su se školovali uz pomoć stručnih komunikacijskih posrednica i znakovnog jezika. Ova eksperimentalna skupina (E1) imala je ukupno 46 sudionika. Druga eksperimentalna skupina (E2; N= 59) nije imala G/NGL učenike, ali je također bila obuhvaćena programom. Osim njih, u istraživanju je sudjelovalo još 95 sudionika. U njihovim razredima nije bilo G/NGL učenika i s njima program nije proveden. Ovi su sudionici u istraživanju bili kontrolna skupina $(\mathrm{K})$.

\section{Program senzibiliziranja za specifičnosti G/ NGL učenika}

U dostupnoj literaturi nismo naišli na primjer i evaluaciju nekog programa senzibiliziranja za potrebe G/NGL učenika za srednjoškolce. Stoga je, u suradnji sa Savezom gluhih i nagluhih osoba grada Zagreba, takav program kreiran za potrebe konkretne sredine kako bi se pokušalo pridonijeti inkluziji G/NGL učenika koji se tu školuju. Program je intenzivno provođen tijekom dvomjesečnog raz- doblja u proljeće 2016. godine, a konkretne aktivnosti trajale su po osam sati u svakom obuhvaćenom razredu. Sastavljen je na osnovi iskustvenih podataka provoditelja i dostupnih istraživanja o faktorima važnim za formiranje stavova prema G/NGL osobama. Karamatić, Brčić (2012) govore o potrebi razvoja svijesti kod učenika o prihvaćanju i uvažavanju različitosti, dok Antia i sur. (2002) te Black (2011) ističu potrebu upoznavanje učenika s kulturom G/NGL i znakovnim jezikom. Upoznavanje čujućih učenika sa znakovnim jezikom pridonosi boljoj uključenosti G/NGL učenika u redovnim školama (Bosnar i Bradarić- Jončić, 2008).

Program je uključivao je po dva predavanja za učenike koja su se bavila kulturom G/NGL osoba, poznatim G/NGL osobama kroz povijest i danas, zakonskom regulativom i zadaćama stručnih komunikacijskih posrednika koji rade s G/NGL učenicima. Učenicima su se predstavljale dvije mlade gluhe osobe koje su s uspjehom završile fakultet. Opisale su svoja iskustva tijekom školovanja i izvore podrške te su na taj način bile pozitivni model mogućeg uspjeha bez obzira na gluhoću. S učenicima su provedene i dvije radionice u kojima su učili osnove jednoručne abecede i osnove Hrvatskog znakovnog jezika. Program je uključio i jedno predavanje s radionicom i za nastavnike budući da pozitivan stav nastavnika može biti značajan za ukupno razredno ozračje i bolje prihvaćanje G/NGL učenika. Trajanje programa bilo je prilagođeno potrebama školskog kurikuluma.

\section{Varijable i mjerni instrumenti}

Za potrebe istraživanja preveden je i adaptiran (Prilog 1) Inventar inkluzije gluhih i nagluhih učenika (Hung, H.L., 2005), uz suglasnost autora mjernog instrumenta. Originalan naziv mjernog instrumenta je ,Inclusion of Students who are Deaf or Hard of Hearing Inventory “. Sastoji se od ukupno pet subskala: ,, Inclusion “ koja mjeri stav prema inkluziji G/NGL učenika, ,C Contact experience" koja mjeri količinu kontakta s osobama s različitim teškoćama, ,, Closeness “ koja mjeri percepciju bliskosti s G/NGL učenikom, ,, Class standards “ koja mjeri razredno ozračje u odnosu na integraciju G/NGL učenika i ,, General information " koja sadrži opće podatke o sudionicima. (spol, vrsta škole, postoje li u školi integrirani G/ 
NGL učenici i sl.). U ovome su istraživanju korištene tri subskale: skala Bliskost koja je prilagođena i nazvana Skala percipirane bliskosti, skala Kontakt i skala Razredni standardi koja je nazvana Skala percepcije razrednog ozračja. Skale su u odnosu na originalne skraćene iz nekoliko razloga: zbog razlika u programima i načinu organiziranja nastave između američkih i hrvatskih učenika, neke originalne tvrdnje za naše učenike nisu bile smislene. Pored toga, materijalni i vremenski resursi koji su bili na raspolaganju utjecali su na duljinu primijenjenog instrumentarija. Prikupljeni su i opći podatci o sudionicima: spol, razred, ima li u razredu integriranih G/NGL učenika, je li sudionik sudjelovao u više od polovine aktivnosti iz programa senzibiliziranja za potrebe G/NGL učenika, ali ova pitanja nisu postavljena $u$ formi subskale kao $\mathrm{u}$ originalnom mjernom instrumentu.

Stav prihvaćanja G/NGL učenika (varijabla STAV) mjeren je Skalom percipirane bliskosti Likertovog tipa. Skala ima osam čestica kojima je iskazan stupanj bliskosti u druženju, odnosima i kontaktima s G/NGL učenicima. Sudionici su odgovarali odabirom jedne od ponuđenih skalnih točaka (u potpunosti se ne slažem; ne slažem se; nisam siguran, donekle se ne slažem; nisam siguran, donekle se slažem; slažem se; u potpunosti se slažem). Rezultat je izračunat kao kompozitna varijabla zbrajanjem rezultata na svim skalnim česticama, uz prethodno izmijenjen smjer pojedinih čestica prema ključu za odgovore. Veći rezultat znači veću iskazanu bliskost, odnosno pozitivniji stav. Najveći rezultat kojeg sudionici mogu postići na ovoj skali je 48. Skala je u oba mjerenja pokazala dobru pouzdanost. U prvoj primjeni, pouzdanost izražena Cronbach alfa indeksom bila je 0.79 , a u drugoj 0.82 . U originalnoj verziji skala Bliskost (Closeness) ima 15 čestica. U hrvatskoj verziji isključene su čestice koje nisu u skladu s najčešćim iskustvom naših učenika u školi, a odnose se na npr. uključivanje u izvanškolski klub, zajednički odlazak na javni bazen, planinarenje, ručak, uključivanje u grupu za učenje.

Podatci o učestalost prethodnih dobrovoljnih osobnih kontakata sudionika s G/NGL učenicima (varijabla KONTAKT) dobiveni su odgovorima na pitanja: Koliko često susrećeš i dobrovoljno kontaktiraš s učenicima koji su G/NGL? Koliko često u svome razredu dobrovoljno kontaktiraš s učenicima koji su G/NGL? Učenici su mogli odabrati jedan od pet ponuđenih odgovora (svakodnevno ili gotovo svakodnevno; jednom tjedno; 1-3 puta mjesečno; 1-10 puta u godini; nikad ili gotovo nikad). Prilikom obrade podataka veći broj pridružen je odgovoru koji ukazuje na češći kontakt. Najveći mogući rezultat je 10. Ukupni rezultat predstavlja kompozitnu varijablu odgovora na ovim česticama. Pouzdanost izražena Cronbach alfa indeksom u prvoj je primjeni bila 0.83 , a u drugoj 0.73 . U originalnom instrumentu kontakt (Contact expirience) je mjeren na skali koja je sadržavala 8 čestica, od kojih se šest odnosilo na G/NGL osobe, a dvije na osobe s ostalim teškoćama. Pri adaptaciji skale, zadržane su samo dvije čestice koje su dovoljno dobro mogle razlikovati sudionike po količini prethodnog kontakta.

Podatci o percepciji razrednog ozračja u odnosu na integraciju G/NGL učenika (varijabla RAZREDNO OZRAČJE) prikupljeni su skalom Likertova tipa od dvanaest čestica. Sudionici su odgovarali odabirom jedne od šest ponuđenih skalnih točaka (u potpunosti se ne slažem; ne slažem se; nisam siguran, donekle se ne slažem; nisam siguran, donekle se slažem; slažem se; u potpunosti se slažem). Rezultat je izračunat kao kompozitna varijabla zbrajanjem brojeva pridruženih odabranim skalnim točkama, uz prethodno izmijenjen smjer pojedinih čestica prema ključu za odgovore. Najveći mogući rezultat je 72 . Veći rezultat označava pozitivniju percepciju razrednog ozračja prema integraciji. U prvoj primjeni, pouzdanost skale izražena Cronbach alfa indeksom bila je 0.80 , a u drugoj 0.86 . U originalnoj verziji subskala Razredni standardi (Class standards) ima 14 čestica. Isključene su dvije koje su imale negativnu konotaciju koju se svakako željelo izbjeći (mišljenje da G/NGL ne bi uopće smjeli biti u redovnim razredima javnih škola i tendencija zadirkivanja G/NGL učenika u razredu). Korištene skale su u prilogu.

U istraživanju su korištene su još dvije dihotomne varijable: prisustvo G/NGL učenika u razredu (Da ili NE) te sudjelovanje u programu (DA ili NE).

\section{Način prikupljanja podataka}

Podatci su prikupljeni uz prethodnu suglasnost ravnatelja za provedbu istraživanja i pristanak roditelja. S obzirom na integrirane G/NGL učenike, rad 
na temi bio je dio redovnog rada stručne službe u školi. Sudionici su ispunjavali upitnike tijekom satova razrednih odjela. Prethodno im je ukratko objašnjena svrha istraživanja kao i mogućnost da odbiju sudjelovanje. Primjena upitnika trajala je u prosjeku dvadesetak minuta i bila je anonimna, uz šifriranje zbog prikupljanja podataka u dvije vremenske točke. Za integrirane G/NGL učenike, sastavljen je poseban upitnik o tome kako percipiraju prihvaćenost u svome razredu te o pozitivnim i negativnim aspektima školovanja u redovnom razredu, što je kasnije iskorišteno u savjetovanju s njima.

\section{Metode obrade podataka}

Osim deskriptivne statistike, u obradi prikupljenih podataka i odgovaranju na postavljene probleme korišteni su t-testovi, analiza varijance $i$ standardna regresijska analiza.

\section{REZULTATI I RASPRAVA}

Pri obradi rezultata izračunati su osnovni deskriptivni podatci za sve sudionike (Tablica 1). $\mathrm{U}$ istoj su tablici su i podatci za druge korištene varijable. Iako razlike u ovim varijablama nisu bile predmet interesa ovog istraživanja, zanimljivo je uočiti da su rezultati na razini svih sudionika po varijablama vrlo slični u oba mjerenja. Stavovi se mogu analizirati na kontinuumu kojem su pozitivni i negativni stavovi zapravo krajnje točke, između kojih stavovi mogu biti manje ili više povoljni ili nepovoljni, odnosno, manje ili više pozitivni ili negativni. S obzirom na broj skalnih čestica i mogući teoretski raspon odgovora od 8-48 (pri čemu je najmanje pozitivnom odgovoru pridružen kod 1, a najpozitivnijem je pridružen kod 6), rezultat manji od 16 ukazivao bi na negativan stav prema G/NGL učenicima, odnosno percipiranu veću distancu. Takav rezultat postigao bi sudionik koji je odgovarao na način da su njegovi odgovori pri obradi podataka imali pridružen kod 1 ili 2 . Rezultat između 24 i 32 ukazivao bi na nesiguran stav. Takav bi rezultat imao sudionik koji bi na svih 8 čestica odgovorio odgovorom ,nisam siguran, donekle se ne slažem" ili "nisam siguran, donekle se slažem" (odgovori kodirani s 3 i 4). Rezultat u rasponu od
40-48 ukazivao bi na vrlo pozitivan stav (odgovori kodirani s 5 i 6 ).

Prosječan rezultat svih sudionika je 39.98 u prvome mjerenju i 41.17 u drugome mjerenju, što ukazuje na visoku iskazanu bliskost, odnosno, vrlo pozitivan stav (Tablica 1). Iz Tablice 2 vidljivo je da su prosječni rezultati svih skupina sudionika vrlo slični, kako u prvome, tako i u drugome mjerenju i svi ukazuju na pozitivne stavove. Podatci o karakteristikama raspodjele rezultata pokazuju da se distribucije ne razlikuju statistički značajno od normalne raspodjele.

Dobiveni rezultati potvrđuju prvu postavljenu hipotezu. Pozitivni stavovi prema G/NGL učenicima u skladu su s prethodnim nalazima (Hung, 2005; Nunes, 2001). Druga hipoteza nije potvrđena. Očekivali smo da će stavovi biti pozitivniji u razredima u kojima postoje G/NGL učenici, što nije potvrđeno, nego je dobiveno upravo suprotno. Korištenjem t-testa za velike nezavisne uzorke provjerili smo razliku na varijabli STAV između E1 i E2 skupine u prvome mjerenju (prije provedbe programa). Dobiveni rezultat $(\mathrm{t}=-4.40, \mathrm{df}=103$; $\mathrm{p}<0.001)$, ukazuje na postojanje statistički značajne razlike. Vrijednosti aritmetičkih sredina pokazuju da je početni stav skupine koja nema G/NGL učenike u razredu bio pozitivniji u odnosu na sudionike koji u razredu imaju G/NGL učenike, što je upravo suprotno našim očekivanjima i prethodnim istraživanjima (Hung, 2005). Boravak G/NGL osobe u razredu osigurava veću mogućnost kontakta, a više kontakta povezano je s pozitivnijim stavovima (Leutar i Štambuk, 2006). Ispitujući stavove djece i njihovih roditelja prema G/NGL osobama koje su živjele u blizini škole za gluhe Dimoski i suradnici (2013) pokazali su da je s pozitivnijim stavovima povezan čak i sasvim površni kontakt. Kako objasniti neočekivani rezultat koji smo dobili u ovom istraživanju? Vjerojatno je da učenici zapravo nemaju realističan uvid u teškoće komunikacije G/NGL osoba. S obzirom na nedostatna iskustva i razumijevanje problema i posljedica gluhoće, moguće je da učenici percipiraju da integrirani učenici imaju ,privilegije“ jer im pomaže stručni komunikacijski posrednik te imaju druge prilagodbe u okviru individualiziranog pristupa. Blizak odnos G/NGL učenika s komunikacijskim posrednikom može djelovati i kao socijalno izolirajući čimbenik, što može utjecati na stav, a 
Tablica 1. Osnovni deskriptivni podatci korištenih varijabli u dva mjerenja

\begin{tabular}{|c|c|c|c|c|c|c|}
\hline & $\begin{array}{l}\text { Stav 1 } \\
N=105\end{array}$ & $\begin{array}{l}\text { Stav } 2 \\
N=200\end{array}$ & $\begin{array}{c}\text { Kontakt } 1 \\
\mathrm{~N}=105\end{array}$ & $\begin{array}{c}\text { Kontakt } 2 \\
\mathbf{N}=\mathbf{2 0 0}\end{array}$ & $\begin{array}{c}\text { Razredno ozračje } 1 \\
\qquad N=105\end{array}$ & $\begin{array}{c}\text { Razredno ozračje } 2 \\
N=200\end{array}$ \\
\hline M & 39.98 & 41.17 & 6.04 & 5.14 & 52.36 & 52.96 \\
\hline SD & 5.27 & 4.60 & 3.23 & 2.93 & 7.39 & 8.39 \\
\hline TR & $23-48$ & $28-48$ & $2-10$ & $2-10$ & $32-67$ & $24-72$ \\
\hline K-S & 1.05 & 1.09 & 1.98 & 1.24 & 1.18 & 0.93 \\
\hline asimetrija & -0.78 & -0.49 & 0.02 & 0.58 & -0.56 & -0.41 \\
\hline spljoštenost & 0.58 & -0.11 & -1.64 & -1.02 & 0.23 & 0.19 \\
\hline
\end{tabular}

1=prvo mjerenje; 2 = drugo mjerenje; $\mathrm{M}=$ aritmetička sredina, $\mathrm{SD}=$ standardna devijacija; $\mathrm{TR}=$ totalni raspon rezultata; $\mathrm{N}=$ broj sudionika; K-S= Kolomogorov- Smirnov test normaliteta raspodjele; asimetrija i spljoštenost= karakteristike krivulje raspodjele rezultata

Tablica 2. Osnovni deskriptivni podatci za varijablu stav u dva mjerenja po skupinama

\begin{tabular}{|c|c|c|c|}
\hline & $\begin{array}{l}\mathrm{E} 1 \\
\mathrm{~N}=46\end{array}$ & \begin{tabular}{|l}
$\mathrm{E} 2$ \\
$\mathrm{~N}=59$
\end{tabular} & $\begin{array}{l}K \\
N=95\end{array}$ \\
\hline \begin{tabular}{|l|} 
Stav 1 \\
\end{tabular} & $\begin{array}{l}\mathrm{M}=37.60 \\
\mathrm{SD}=5.62 \\
\mathrm{TR}=23-47 \\
\mathrm{~K}-\mathrm{S}=0.86 \\
\text { asim=-0.65 } \\
\text { spljošt }=0.09\end{array}$ & $\begin{array}{l}\mathrm{M}=41.86 \\
\mathrm{SD}=4.14 \\
\mathrm{TR}=32-48 \\
\mathrm{~K}-\mathrm{S}=0.82 \\
\text { asim }=-0.45 \\
\text { spljošt }=-0.46\end{array}$ & \\
\hline Stav 2 & $\begin{array}{l}\mathrm{M}=38.68 \\
\mathrm{SD}=4.67 \\
\mathrm{TR}=28-48 \\
\mathrm{~K}-\mathrm{S}=0.63 \\
\text { asim=0.03 } \\
\text { spljošt }=-0.37\end{array}$ & $\begin{array}{l}\mathrm{M}=42.85 \\
\mathrm{SD}=4.04 \\
\mathrm{TR}=33-48 \\
\mathrm{~K}-\mathrm{S}=0.80 \\
\text { asim }=-0.55 \\
\text { spljošt }=-0.38\end{array}$ & $\begin{array}{l}\mathrm{M}=41.29 \\
\mathrm{SD}=4.52 \\
\mathrm{TR}=28-48 \\
\mathrm{~K}-\mathrm{S}=0.82 \\
\text { asim }=-0.68 \\
\text { spljošt }=0.58\end{array}$ \\
\hline
\end{tabular}

1= prvo mjerenje, 2= drugo mjerenje; E1= u razredu imaju gluhog učenika, obuhvaćeni programom; E2=u razredu nemaju gluhog učenika, obuhvaćeni programom; $\mathrm{K}=\mathrm{u}$ razredu nemaju gluhog učenika, nisu obuhvaćeni programom; $\mathrm{M}=$ aritmetička sredina, $\mathrm{SD}=$ standardna devijacija; $\mathrm{TR}=$ totalni raspon rezultata; $\mathrm{N}=$ broj sudionika; $\mathrm{K}-\mathrm{S}=\mathrm{Kolomogorov}-\mathrm{Smirnov}$ test normaliteta raspodjele; asimetrija i spljoštenost= karakteristike krivulje raspodjele rezultata

što nismo kontrolirali. Pored toga, nismo ispitali kvalitetu prethodnog iskustva u kontaktima s G/ NGL, što je također moglo imati utjecaja. Nije kontroliran doprinos ličnosti G/NGL učenika kao niti kvaliteta njihovog odnosa prema čujućim vršnjacima, što je također moglo utjecati na dobivene rezultate. Važnost kvalitete prethodnih kontakata naglasili su u svom istraživanju De Laat i suradnici (2013). U našem je istraživanju taj čimbenik mogao biti važan, tim više što se radilo o iskustvu s vrlo malim brojem G/NGL vršnjaka. Pored toga, bez vladanja zajedničkim jezikom teško je ostvariti istinsku bliskost.

Kako bismo odgovorili na drugi postavljeni cilj provjerili smo postoje li razlike u iskazanim stavovima unutar E1 i E2 skupine prije i nakon provedbe programa. Korišteni su t- testovi za velike zavisne uzorke koji su pokazali da ne postoji statistički značajna razlika. Dobivena vrijednost t-testa za E1 skupinu je $\mathrm{t}=-0.27, \mathrm{df}=44$, a za E2 skupinu $\mathrm{t}=-1.93, \mathrm{df}=56 \mathrm{uz} \mathrm{p}>0.005$. Time treća hipoteza nije potvrđena, što nije u skladu s očekivanjima. Kako bismo provjerili postojanje razlika između tri skupine sudionika nakon provedenog programa, odnosno dodatno provjerili efikasnost provedenog programa, koristili smo analizu varijance. Dobiveni F omjer $(\mathrm{F}=11,27, \mathrm{df}=2 / 197, \mathrm{p}<0.001)$ pokazao se statistički značajnim. Post-hoc analizom potvrđene su statistički značajne razlike uz $\mathrm{p}<0.001$ između E1 i preostalih dviju skupina, dok razlika između E2 i K nije bila značajna. Uvidom u Tablicu 2 može se uočiti da je aritmetička sredina E1 skupine manja od ostalih dviju, što ukazuje na to da je ova skupina sudionika iskazala najmanje pozitivan stav prema G/NGL učenicima. Provedeni program nije imao utjecaja na stavove učenika, odnosno, nije se 
pokazao efikasnim. Pored toga, stav je najmanje pozitivan kod učenika koji u razredu imaju G/NGL učenika. Za ovakav neočekivani rezultat postoji više mogućih objašnjenja $i / i$ ili njihovih kombinacija. Program je bio ipak prekratak da bi polučio mjerljive promjene. S obzirom da u kreiranju programa nismo imali neki dostupni prethodno evaluiran program, moguće je da u njegovu kreiranju nisu obuhvaćeni sadržaji koji bi bili relevantni i dovoljno zanimljivi učenicima. Nadalje, radi se o učenicima drugih razreda u kojima se G/NGL učenici školuju već drugu godinu, pa se promjene možda nisu mogle zamijetiti jer su prethodna iskustva iz prvog razreda bila daleko važniji faktor i stav je već formiran. Iskazani stavovi su općenito pozitivni pa je i mogućnost variranja rezultata smanjena. Potrebno je reći i to da se pitanja skale koja mjeri percepciju bliskosti velikim dijelom odnose na aktivnosti koje zahtijevaju komunikaciju i dobru razinu vladanja jezikom, što G/NGL učenici nemaju. Uz posrednika, a bez zajedničkog jezika teško je ostvariti istinsku bliskost $\mathrm{i}$ očekivati poboljšanje u stavovima i interakcijama.

Za procjenu mogućnosti predviđanja stava $u$ drugome mjerenju korištena je regresijska analiza (Tablica 4). Prethodno je izračunata korelacijska matrica uvrštenih varijabli (Tablica 3 ). Iako je korelacijski koeficijent najviši za varijable prethodni kontakt i prisustvo G/NGL učenika u razredu, preliminarne analize pokazale su da pretpostavke o normalnosti raspodjele, linearnosti i kolinearnosti nisu bitno narušene. Kao prediktorske varijable uzete su varijable iz drugog mjerenja: uključenost $u$ program, prisutnost G/NGL učenika u razredu, učestalost prethodnih dobrovoljnih kontakta s G/NGL učenicima, percepcija razrednog ozračja u odnosu na integraciju. Sve su prediktorske varijable uvedene u model istovremeno, odnosno, korištena je standardna višestruka regresija.

Model objašnjava zadovoljavajućih 33\% ukupne varijance $\left(R^{2}=0.33\right)$. Statistički su značajni prediktori prisutnost $\mathrm{G} / \mathrm{NGL}$ učenika u razredu, pri čemu je beta koeficijent ovog prediktora $\beta=.50$; percepcija razrednog ozračja prema integraciji s beta koeficijentom $\beta=.46$ te učestalost prethodnog dobrovoljnog osobnog kontakta s G/NGL čiji je beta koeficijent $\beta=.28$. Dakle, kad se doprinos svih varijabli sagledava zajednički, veću bliskost s G/ NGL vršnjacima moguće je predvidjeti na osnovi informacije o tome postoji li G/NGL učenik u razredu, koliko je bilo prethodnog dobrovoljnog kontakta s G/NGL i u kojoj mjeri se percipira da razred prihvaća integraciju. Važnost prethodnog dobrovoljnog kontakta kao prediktora pozitivnijeg stava može se donekle komentirati kao neku vrstu informacije o kvaliteti prethodnog odnosa. Za očekivati je da će dobrovoljni kontakti biti učestaliji ukoliko su prethodni bili kvalitetniji, što bi bilo u skladu s rezultatima o kojima izvještavaju de Laat i suradnici (2013), a u skladu je i s Allportovom

Tablica 3. Korelacijska matrica varijabli uključenih u regresijski model

\begin{tabular}{|l|c|c|c|c|c|}
\hline & $\mathbf{1 .}$ & $\mathbf{2 .}$ & $\mathbf{3 .}$ & $\mathbf{4 .}$ & $\mathbf{5 .}$ \\
\hline 1.stav & 1 & & & & \\
\hline 2. prethodni kontakt & -0.14 & 1 & & & \\
\hline 3.prisustvo G/NGL učenika u razredu & $0.29^{*}$ & $-0.84^{* *}$ & 1 & & \\
\hline 4.program & -0.02 & $0.37^{* *}$ & $-0.52^{* *}$ & 1 & \\
\hline 5.razredno ozračje & $0.49^{* *}$ & -0.03 & 0.08 & $0.24^{*}$ & 1 \\
\hline
\end{tabular}

$* * \mathrm{p}<.001 ; * \mathrm{p}<.005$

Tablica 4. Rezultati standardne višestruke regresije za kriterijsku varijablu Stav prema G/NGL vršnjacima

\begin{tabular}{|l|c|}
\hline Kriterijska varijabla & Stav prema gluhim i nagluhim vršnjacima \\
\hline Prediktorske varijable & $\boldsymbol{\beta}$ \\
\hline prethodni kontakt & $.28^{* *}$ \\
prisustvo G/NGL učenika u razredu & $.50^{* *}$ \\
program & .02 \\
razredno ozračje & $.46^{* *}$ \\
\hline $\mathbf{R}^{\mathbf{2}}=\mathbf{0 . 3 3} ; \mathbf{F}=\mathbf{2 3 . 3 1}, \mathbf{p} * * \mathbf{d f}=\mathbf{4 / 1 9 6}$ & \\
\hline
\end{tabular}

${ }^{* *} \mathrm{p}<.001 ; \beta=$ Beta koeficijent; $\mathrm{R}^{2}=$ ukupni doprinos svih prediktora $\mathrm{u}$ objašnjenoj varijanci kriterijske varijable 
hipotezom kontakta (Allport, 1954). Provedeni program ni na koji način ne pridonosi predviđanju stava, kako je to i očekivano s obzirom na prethodno provedene analize.

\section{ZAKLJUČAK}

Istraživanje je provedeno kako bi se ispitali stavovi srednjoškolaca prema G/NGL vršnjacima te evaluirao program senzibiliziranja za specifičnosti ove skupine učenika. Općenito, stavovi prema G/ NGL vršnjacima bili su pozitivni. Pozitivniji stavovi mogu se predvidjeti na osnovi informacije o postojanju G/NGL učenika u razredu, većoj učestalosti prethodnih dobrovoljnih kontakata s G/NGL te percepciji učenika da je razredno ozračje u odnosu na integraciju G/NGL pozitivnije. Provedeni program kojem je cilj bio senzibilizacija za specifičnosti G/NGL učenika nije ni na koji način pridonio promjeni stavova učenika. Rezultati ukazuju i na to koliko je daleko od integracije do inkluzije G/ NGL u redovnom odgojno- obrazovnom sustavu. No, kako su stavovi relativno stabilni, možda nije bilo ni opravdano očekivati da će provođenje ovako kratkog programa imati brzi učinak prema još pozitivnijim stavovima. Valjanost ovog istraživanja i mogućnost generaliziranja zaključaka ograničena je iz više razloga. Istraživanje je provedeno na prigodnom uzorku učenika. Nisu kontrolirani neki relevantni čimbenici koji su mogli imati značajan utjecaj na rezultate, npr. karakteristike ličnosti G/
NGL učenika i njihovog odnosa prema čujućim vršnjacima. Iako je odgovaranje bilo anonimno, učenici su rabili lozinke zbog mogućnosti ponovljenog ispitivanja nakon provedenog programa $\mathrm{i}$ moguće je da su davali socijalno poželjne odgovore. Kvaliteta kreiranog programa trebala je biti preliminarno ispitana kako bi program bio sadržajniji i na atraktivniji način prikazao specifičnosti G/ NGL osoba.

Ipak, prema nama dostupnim podatcima, ovo je u Hrvatskoj prvi pokušaj kreiranja i evaluacije programa senzibiliziranja srednjoškolaca za potrebe G/NGL vršnjaka u uvjetima konkretne odgojno-obrazovne sredine. U tome je smislu provedeno istraživanje vrijedno i može biti poticajno za razvijanje proširenog programa u duljem trajanju, koji bi mogao pomoći inkluziji G/NGL učenika u redovnome sustavu.

Predloženi program trebalo bi provoditi u duljem vremenskom razdoblju. Potrebno ga je dopuniti atraktivnijim sadržajima, npr. prikazati rad i uspjehe mladih G/NG osoba u područjima koja srednjoškolskim učenicima mogu biti osobito zanimljiva- npr. u području glazbe ili mode. Ipak, dokle god budu postojale jezične barijere, teško je postići istinsku bliskost, stoga je potrebno uvesti mogućnost učenja hrvatskog znakovnog jezika u razredima gdje su integrirani G/NGL učenici. 


\section{LITERATURA}

Allport, G.(1954): The Nature of Prejudice. Cambridge: Mass., Addison-Wesley Pub. Co.

Black, M. (2011): Inclusion and deaf education: the perceptions andexperiences of young deaf people in Northern Ireland and Sweden. Posjećeno 13.03.2017. na mrežnoj stranici: https://www.academia.edu/1532427/ .

Bosnar, B., Bradarić- Jončić, S. (2008): Stavovi prema integraciji gluhe djece, znakovnom jeziku i uključivanju tumača za znakovni jezik u redovne vrtiće i škole. Hrvatska revija za rehabilitacijska istraživanja, 44, 2, 11-30.

Bosnar, B., Bradarić-Jončić, S. (2006): Stavovi prosvjetnih djelatnika prema uključivanju gluhe djece i mladeži u redovne škole i vrtiće. Zbornik radova sa znanstveno -stručnog skupa s međunarodnom suradnjom Peti dani osnovne škole Splitsko-dalmatinske županije: Prema kvalitetnoj školi (str. 151-164), Hicela, I. (ur.), 16.-18.11.2006. Split:, Hrvatski- pedagoško književni zbor -Ogranak Split i Filozofski fakultet Sveučilište u Splitu.

Bouillet, D.(2014): Nevidljiva djeca- od prepoznavanja do inkluzije. Zagreb: Ured UNICEF-a za Hrvatsku.

De Laat, S., Freriksen, E., Vervloed, M.P.J.(2013): Attitudes of children and adolescents toward persons who are deaf, blind, paralyzed, or intellectually disabled. Research in Developmental Disabilities. Posjećeno 06.01.2017. na mrežnoj stranici https://www.utwente.nl/en/bms/pcrv/staff/phdandresearch/.

Dimoski, S., Eminović, F., Stojković, I., Stanimirović, D. (2013): Contact with Persons with Hearing Impairments as a Correlate of Children's and Adults' Attitudes towards These Persons. Croatian Journal of Education, 15, 3, 611-628.

Dulčić, A., Bakota, K. (2008): Stavovi učitelja povijesti redovnih osnovnih škola prema integriranim učenicima oštećena sluha i učenicima s poremećajima govorno -jezične komunikacije te specifičnim teškoćama u učenju. Hrvatska revija za rehabilitacijska istraživanja,44, 2, 31-50.

Farber, G.B.S. (2015): Social Perception toward Deafness: How could it influence Deaf Identity Development and the Deaf Community. Gallaudet Chronicles of Psychology, 3, 1, 10-13.

Hindley, P., Kitson, N. (2000): Mental Health and Deafness. London:Whurr Publishers.

Hung, H-L.(2005): Factors associated with the attitudes of nondisabled secondary school students toward the inclusion of peers who are deaf or hard of hearing in their general education classes. Doktorska disertacija. The Ohio State University. Posjećeno 01.01.2016. na mrežnoj stranici: https://etd.ohiolink.edu/rws_etd/document/get/ osu1110389807/inline/.

Imširagić, A.(2012): Humane pretpostavke inkluzivnog obrazovanja učenika oštećenog sluha. Život i škola, 27, 1, 94-103.

Ivasović, V. (2014): I ja želim znati. Gluhi i nagluhi učenik u redovnoj školi. Zagreb: Hrvatski savez gluhih i nagluhih.

Kiš-Glavaš, L, Pantić, Z. (2002): Različitost. U: Kiš-Glavaš, L., Fulgosi-Masnjak, R. (ur.). Do prihvaćanja zajedno: integracija djece s posebnim potrebama. (str. 45-63). Zagreb: Hrvatska udruga za stručnu pomoć djeci s posebnim potrebama - IDEM.

Kunac, S. (2015): Razumijevanje različitosti - gluhe osobe i znakovni jezik. Zbornik radova znanstveno-stručnog skupa s međunarodnom suradnjom Deseti dani osnovne škole Splitsko-dalmatinske županije: Prema kvalitetnoj školi (str. 15-22), Hicela,I. i Tomaš,S. (ur.), 23.-25.04.2015. Split: Hrvatski pedagoško-književni zbor-Ogranak Split i Filozofski fakultet Sveučilište u Splitu, Odsjek za Učiteljski studij.

Konvencija o pravima osoba s invaliditetom UN (2007)

Leutar, Z.; Štambuk, A. (2006): Stavovi mladih prema osobama s tjelesnim invaliditetom. Revija za sociologiju, 1-2, 91-102.

Leutar, Z. (2002.). Slobodno vrijeme i socijalna integracija osoba s invaliditetom. U: Pospišil. M. (ur): Zbornik radova Znanjem do izjednačavanja mogućnosti za osobe s invaliditetom.(str. 123-132). Zagreb: Hrvatski savez udruga cerebralne i dječje paralize, Savez distrofičara Hrvatske. 
Mustać, V. (1977): Struktura stavova roditelja prema djeci s oštećenim sluhom koja su pod utjecajem rehabilitacijskog postupka u zavodima za rehabilitaciju slušno oštećene djece i omladine. Magistarski rad. Medicinski fakultet Sveučilišta u Zagrebu.

Najman Hižman, E., Leutar, Z., Kancijan. S. (2008): Stavovi građana prema osobama s invaliditetom u Hrvatskoj u usporedbi s Europskom unijom. Soc. ekol. Zagreb, 17,1. 71-73.

Nunes, T., Pretzlik, U., Olsson,J.(2000): Deaf childrens social relationships in mainstream schools. Journal of Deaf Studies and Deaf Education, 3, 123-126.

Oberman-Babić, M.(1987): Stavovi učenika redovne iv specijalne škole prema odgojno-

obrazovnoj integraciji djece sa smetnjama u razvoju. Doktorska disertacija. Fakultet za defektologiju Sveučilišta u Zagrebu.

Pravilnik o osnovnoškolskom i srednjoškolskom odgoju i obrazovanju učenika s teškoćama u razvoju: Narodne novine br. 24/2015.

Pribanić. Lj., Milković,M. (2016): Gluhi pacijent u sustavu zaštite zdravlja. Posjećeno 01.01.2017. na mrežnoj stranici: https://www.researchgate.net/publication/289479459.

Radovančić, B.(1994): Kongruencija latentnih prostora stavova roditelja učenika s oštećenim sluhom i roditelja učenika koji čuju prema odgojno-obrazovnoj integraciji učenika s oštećenim sluhom. Defektologija, 30,1, 9-32.

Radovančić, B.(1985): Stavovi nastavnika prema odgojno-obrazovnoj integraciji djece s oštećenim sluhom. Defektologija, 21,2,49-62.

Registar osoba s invaliditetom (2015). Zagreb: Hrvatski zavod za javno zdravstvo, Služba za javno zdravstvo, Ministarstvo zdravstva i socijalne skrbi.

Stančić, V. (1982): Odgojno-obrazovna integracija djece s teškoćama u razvoju. Ispitivanje objektivnih i subjektivnih pretpostavki za uključivanje djece s razvojnim smetnjama u redovne škole zagrebačke regije. Zagreb: Fakultet za defektologiju Sveučilišta u Zagrebu.

Teruggi, L.A. (ur.) (2014): Jedna škola, dva jezika. Iskustvo dvojezičnosti u vrtiću i osnovnoj školi u Cossatu. Zagreb: URIHO.

Uzelac, M. (1989):Subjektivne pretpostavke odgojno-obrazovne integracije djece s oštećenim sluhom, Magistarski rad. Fakultet za defektologiju Sveučilišta u Zagrebu.

World Health Organization. Deafness and Hearing Loss. (2012). Posjećeno 01.01.2017. na mrežnoj stranici WHO: http://www.who.int/mediacentre/factsheets/fs300/en/.

Yuker, H.E. (1988). The effects of contact on attitudes toward disabled persons: Some empirical generalizations. U: Yuker, H.E.(Ur.), Attitudes toward persons with disabilities (str. 62-274). New York: Springer.

Zakon o odgoju i obrazovanju u osnovnoj i srednjoj školi: Narodne novine br . 87/2008.

Zakon o odgoju i osnovnom obrazovanju u SR Hrvatskoj: Narodne novine br. 4/1980. 


\section{PRILOG 1}

\section{SKALA PERCIPIRANE BLISKOSTI}

Odgovori oznakom X na sva pitanja u tablici. Gluhe i nagluhe osobe označene su kraticom (G/NGL). Ukoliko nema G/NGL učenika u razredu odgovaraj za situaciju kad bi takav učenik ili učenica bili u tvome razredu.

\begin{tabular}{|l|l|l|l|l|l|l|}
\hline & $\begin{array}{l}\text { U potpunosti } \\
\text { se NE slažem }\end{array}$ & NE slažem se & $\begin{array}{l}\text { Nisam } \\
\text { siguran, ali } \\
\text { donekle se } \\
\text { NE slažem }\end{array}$ & $\begin{array}{l}\text { Nisam } \\
\text { siguran, ali } \\
\text { donekle se } \\
\text { slažem }\end{array}$ & Slažem se & $\begin{array}{l}\text { U potpunosti } \\
\text { se slažem }\end{array}$ \\
\hline $\begin{array}{l}\text { G/NGL učenik nikad ne } \\
\text { bi mogao biti moj najbolji } \\
\text { prijatelj. }\end{array}$ & & & & & \\
\hline $\begin{array}{l}\text { Izbjegao bih sjediti s G/NGL } \\
\text { učenikom. }\end{array}$ & & & & & & \\
\hline $\begin{array}{l}\text { Ne bi mi bio problem plesati s } \\
\text { G/NGL učenikom pred ostalima. }\end{array}$ & & & & & & \\
\hline $\begin{array}{l}\text { Pozvao bih G/NGL učenika bilo } \\
\text { kamo kud idem s ostalima. }\end{array}$ & & & & & \\
\hline $\begin{array}{l}\text { Bio bih prijatelj s G/NGL } \\
\text { učenikom kad bi se pružila } \\
\text { prilika. }\end{array}$ & & & & & & \\
\hline $\begin{array}{l}\text { Uvijek bih pomogao G/NGL } \\
\text { učeniku kad bi imao problem. }\end{array}$ & & & & & & \\
\hline $\begin{array}{l}\text { Volio bih imati G/NGL osobu } \\
\text { za bliskog prijatelja. }\end{array}$ & & & & & \\
\hline $\begin{array}{l}\text { Često bih izmislio izgovor da } \\
\text { izbjegnem kontakt s učenikom } \\
\text { koji je G/NGL }\end{array}$ & & & & & \\
\hline
\end{tabular}

\section{SKALA KONTAKTA}

Odgovori oznakom X na pitanja u tablici. Gluhe i nagluhe osobe označene su kraticom (G/NGL). Ako u tvome razredu nema G/NGL učenika na zadnje pitanje označit ćeš odgovor nikad ili gotovo nikad.

\begin{tabular}{|l|l|l|l|l|l|}
\hline & $\begin{array}{l}\text { Svakodnevno } \\
\text { ili gotovo } \\
\text { svakodnevno }\end{array}$ & Jednom tjedno & $\begin{array}{l}\text { 1-3 puta } \\
\text { mjesečno }\end{array}$ & $\begin{array}{l}\text { 1-10 puta u } \\
\text { godini }\end{array}$ & $\begin{array}{l}\text { Nikad ili gotovo } \\
\text { nikad }\end{array}$ \\
\hline $\begin{array}{l}\text { Koliko često u svojoj školi } \\
\text { susrećeš ili kontaktiraš s G/ } \\
\text { NGL osobama }\end{array}$ & & & & \\
\hline $\begin{array}{l}\text { Koliko često u svome razredu } \\
\text { kontaktiraš s G/NGL učenikom }\end{array}$ & & & & & \\
\hline
\end{tabular}




\section{SKALA RAZREDNOG OZRAČJA}

Odgovori oznakom X na sva pitanja u tablici. Gluhe i nagluhe osobe označene su kraticom (G/NGL). Ukoliko nema učenika s G/NGL u razredu odgovaraj za situaciju kad bi takav učenik ili učenica bili u tvome razredu.

\begin{tabular}{|c|c|c|c|c|c|c|}
\hline $\begin{array}{l}\text { Većina učenika u mome } \\
\text { razredu }\end{array}$ & $\begin{array}{l}\text { U potpunosti } \\
\text { se } \underline{\text { NE slažem }}\end{array}$ & NE slažem se & $\begin{array}{l}\text { Nisam } \\
\text { siguran, ali } \\
\text { donekle se } \\
\text { NE slažem }\end{array}$ & \begin{tabular}{|l}
$\begin{array}{l}\text { Nisam } \\
\text { siguran, ali } \\
\text { donekle se }\end{array}$ \\
$\underline{\text { slažem }}$
\end{tabular} & Slažem se & $\begin{array}{l}\text { U potpunosti } \\
\text { se slažem }\end{array}$ \\
\hline $\begin{array}{l}\text {...voljeli bi imati G/NGL } \\
\text { učenika u razredu }\end{array}$ & & & & & & \\
\hline $\begin{array}{l}\text {...smatra da G/NGL učenik u } \\
\text { razredu dovodi do remećenje } \\
\text { uobičajenog rada }\end{array}$ & & & & & & \\
\hline $\begin{array}{l}\text {...voljeli bi biti prijatelji s G/ } \\
\text { NGL osobom }\end{array}$ & & & & & & \\
\hline $\begin{array}{l}\text {... smatra da bi svi imali koristi } \\
\text { kad bi imali G/NGL učenika u } \\
\text { razredu }\end{array}$ & & & & & & \\
\hline $\begin{array}{l}\text {...smatra da G/NGL učenici } \\
\text { mogu s ostalima pohađati samo } \\
\text { neke lakše predmete (npr.TZK) }\end{array}$ & & & & & & \\
\hline $\begin{array}{l}\text {...smatra da G/NGL učenici } \\
\text { zauzimaju previše vremena i } \\
\text { pažnje nastavnika }\end{array}$ & & & & & & \\
\hline $\begin{array}{l}\text {...smatra da G/NGL učenici } \\
\text { mogu učiniti sve potrebno } \\
\text { jednako dobro kao i ostali }\end{array}$ & & & & & & \\
\hline $\begin{array}{l}\text {... smatraju da se G/NGL } \\
\text { učenici trebaju uključiti u sve } \\
\text { aktivnosti s ostalima }\end{array}$ & & & & & & \\
\hline $\begin{array}{l}\text {...smatra da G/NGL učenik } \\
\text { u razredu uzrokuje probleme } \\
\text { ostalima }\end{array}$ & & & & & & \\
\hline $\begin{array}{l}\text {...smatra da je moguće biti } \\
\text { blizak prijatelj s G/NGL } \\
\text { učenikom }\end{array}$ & & & & & & \\
\hline $\begin{array}{l}\text {...smatra dobrom idejom imati } \\
\text { odvojene razrede za G/NGL } \\
\text { učenike }\end{array}$ & & & & & & \\
\hline $\begin{array}{l}\text {... smatra da G/NGL učenici } \\
\text { mogu biti konkurentni s } \\
\text { ostalima u svim predmetima }\end{array}$ & & & & & & \\
\hline
\end{tabular}




\title{
RAISING AWARENESS AMONG SECONDARY SCHOOL STUDENTS ABOUT THE NEEDS OF THEIR DEAF AND HARD-OF-HEARING PEERS
}

\begin{abstract}
Although meeting the needs of students with disabilities should be a priority in every school in the country, the inclusion of deaf and hard-of-hearing (D/HH) students in the educational system is still inadequate. A lack of experience, stereotypes and incomplete professional support can have a negative effect on D/HH students' acceptance and their academic and socioemotional development.

The goal of this study was to collect data on the attitudes of secondary school students towards their D/HH peers, as well as to create and evaluate a Programme to raise awareness of their needs.

The Inclusion of Deaf or Hard of Hearing Students Inventory (Hung 2005) was translated and adapted to the Croatian language. It provided the data on hearing students 'perceived closeness to D/HH peers, frequency of their prior voluntary contacts with D/HH peers, and perception of classroom climate related to inclusion. Out of 200 participants (secondary school students, aged between 15.5 and 16.5 years.), 105 of them participated in the Awareness Raising Programme. Forty-six of them were from two classrooms attended by D/HH students, whereas 59 of them attended classes with no D/HH classmates. The remaining 95 students were a control group, which did not participate in the Awareness Raising Programme. Data were collected before and after the implementation of the Programme and analysed using the t test, analysis of variance and standard regression analysis.

The findings show that the perceived closeness to D/HH peers was relatively high, meaning that the attitudes toward them were positive. The least positive attitudes were found in classrooms with a D/HH student. The implemented Programme did not contribute to attitude change. Factors that significantly contributed to the prediction of attitudes were frequent voluntary contact with D/HH students, more positive perception of the classroom climate related to inclusion, and the enrollment of a D/HH student in the classroom. Results are discussed in the context of similar prior research and the efficiency of the implemented Programme. Recommendations for the inclusion of D/HH students in general education classrooms are provided.
\end{abstract}

Key words: attitudes; deaf and hard of hearing students; inclusion 